\title{
QUEEN'S
QNEIVERSITY
BELFAST
}

\section{Lipid content and fatty acid composition of the digital cushion of bulls offered different amounts of linseed}

Baird, L. G., Dawson, L. E. R., Young, I. S., \& O'Connell, N. (2010). Lipid content and fatty acid composition of the digital cushion of bulls offered different amounts of linseed. Journal of Animal Science , 88(7), 2403-2409. https://doi.org/10.2527/jas.2009-1972

Published in:

Journal of Animal Science

Queen's University Belfast - Research Portal:

Link to publication record in Queen's University Belfast Research Portal

\section{General rights}

Copyright for the publications made accessible via the Queen's University Belfast Research Portal is retained by the author(s) and / or other copyright owners and it is a condition of accessing these publications that users recognise and abide by the legal requirements associated with these rights.

Take down policy

The Research Portal is Queen's institutional repository that provides access to Queen's research output. Every effort has been made to ensure that content in the Research Portal does not infringe any person's rights, or applicable UK laws. If you discover content in the Research Portal that you believe breaches copyright or violates any law, please contact openaccess@qub.ac.uk. 


\title{
Lipid content and fatty acid composition of the digital cushion of bulls offered different amounts of linseed ${ }^{1}$
}

\author{
L. G. Baird,* L. E. R. Dawson,* I. S. Young, $\dagger$ and N. E. O'Connell $\ddagger^{2}$ \\ *Agri-Food and Biosciences Institute, Large Park, Hillsborough, Co. Down, Northern Ireland BT26 6DR; \\ †Queen's University Belfast and the Centre for Clinical and Population Sciences, Institute of Clinical Science \\ Building, Belfast, Northern Ireland BT12 6BW; and ‡Queen's University Belfast, Medical Biology Centre, \\ Lisburn Road, Belfast, Northern Ireland BT9 7BL
}

\begin{abstract}
Previous research suggests that the digital cushion, a shock-absorbing structure in the claw, plays an important role in protecting cattle from lameness. This study aimed to assess the degree to which nutritional factors influence the composition of the digital cushion. This involved quantifying lipid content and fatty acid composition differences in digital cushion tissue from cattle offered diets with different amounts of linseed. Forty-six bulls were allocated to 1 of 4 treatments, which were applied for an average of $140 \pm 27 \mathrm{~d}$ during the finishing period. The treatments consisted of a linseed supplement offered once daily on top of the basal diet (grass silage:concentrate) at 0 , 400,800 , or 1,200 g of supplement/animal per day. For each treatment, the concentrate offered was adjusted to ensure that total estimated ME intake was constant across treatments. Target BW at slaughter was $540 \mathrm{~kg}$. Legs were collected in 3 batches after 120, 147 and 185 d on experiment. Six samples of the digital cushion were dissected from the right lateral hind claw of each animal. Lipids were extracted and expressed as a proportion of fresh tissue, and fatty acid composition of
\end{abstract}

the digital cushion was determined by gas chromatography. Data were analyzed by ANOVA, with diet, location within the digital cushion, and their interactions as fixed effects and fat content (grams per $100 \mathrm{~g}$ of tissue) as a covariate. Linear or quadratic contrasts were examined. The lipid content of digital cushion tissue differed between sampling locations $(P<0.001)$ but did not vary by treatment. There were quadratic responses to increasing linseed supplementation for several fatty acids. Although the overall proportion of $\mathrm{C} 18: 3 \mathrm{n}-3$ (the most abundant fatty acid in linseed) did not differ $(P$ $<0.33$ ) by treatment, there was a quadratic influence of diet on total PUFA concentration $(P=0.003)$ and a linear increase in C18:3n-3 as a proportion of total PUFA $(P=0.01)$ in the digital cushion. This work demonstrates that dietary fatty acid composition influences the concentration of fatty acids incorporated in the digital cushion of cattle. Based on the large number of quadratic responses among the fatty acids, it appears there is a threshold amount of fatty acid incorporation in the digital cushion.

Key words: digital cushion, fatty acid, linseed, lipid, n-3 fatty acid

(0)2010 American Society of Animal Science. All rights reserved.

J. Anim. Sci. 2010. 88:2403-2409 doi:10.2527/jas.2009-1972

\section{INTRODUCTION}

In cattle, the digital cushion is a shock-absorbing structure in the claw composed of 3 parallel cylindri-

\footnotetext{
${ }^{I}$ The authors thank G. Finney, K. Mathers, and the staff of the Beef Unit at the Agri-Food and Biosciences Institute for technical assistance. Thank you to C. McMaster for chemical analysis. Thanks also to Marta Rüber of the Universität Bern for her advice on the study design and interpretation. We greatly appreciate funding from the Department of Agriculture and Rural Development (Belfast, Northern Ireland) and AgriSearch (Dungamon, Co. Tyrone, Northern Ireland) for this work.

${ }^{2}$ Corresponding author: niamh.oconnell@qub.ac.uk

Received March 20, 2009.

Accepted March 29, 2010.
}

cal fat pads and connective tissue (Räber et al., 2004, 2006). Finger-like projections connect the axial and abaxial cushions under the third phalanx (Räber, 2000). Because the corium (dermis) of cattle hooves is subject to mechanical load and pressure from above (from the third phalanx) and pressure below (from the hard outer horn capsule), Lischer et al. (2002) suggested that the functional properties and quality of the cushioning tissues under the third phalanx may be fundamental in protecting the corium from contusions and sole lesions. Because the structure of fatty tissues is largely reliant on lipid content and fatty acid composition, it is of interest to determine if these factors can be altered in the digital cushion. 
The fatty acid composition of cattle tissues (inclucling muscle and subcutaneous adipose tissue) can be influenced, at least in part, by the fatty acid composition of the diet (Gläser et al., 2004; Noci et al., 2007). Because there is increasing evidence of the benefits of increasing the amount of n-3 PUFA in human diets, feeding animals to alter tissue fatty acid composition is becoming increasingly common. To our knowledge, no research has been published that shows how diet affects the fatty acid composition of the digital cushion. In light of this, a study was designed to investigate the inclusion of linseed, the richest plant source of $n-3$ fatty acids [predominantly C18:3n-3 (linolenic acid)], in cattle diets. Our aim was to investigate the extent to which the lipid content and fatty acid composition of the digital cushion could be manipulated through diets differing in fatty acid composition. Our hypothesis was thus that the fat pads of the digital cushions of animals fed more linseed would contain more longchain fatty acids and proportionally fewer short-chain fatty acids. We were specifically interested in the influence on MUFA and PUFA foverall content and particularly C18:2n-6 (linoleic acid), C18:3n-3, and C20:4n-6 (arachidonic acid)]. We also investigated the variation in lipid content and fatty acid composition between different parts of the digital cushion.

\section{MATERIALS AND METHODS}

This study did not come under the Animals (1986) Scientific Procedures Act due to its mild nature. Animals received high levels of care by experienced technicians and stockpeople as dictated by the Agri-Food and Biosciences Institute.

\section{Diets and Experimental Design}

Bulls were offered high-quality ryegrass silage and concentrates (forage:concentrate ratio of $45: 55$ on a DM basis) once daily at a rate allowing a refusal of 50 to $100 \mathrm{~g} / \mathrm{kg}$ of intake. The mineral premix fed to all animals in the study consisted of $32,000 \mathrm{IU} / \mathrm{kg}$ of vitamin A, $80,000 \mathrm{IU} / \mathrm{kg}$ of vitamin $\mathrm{D}_{3}, 600 \mathrm{IU} / \mathrm{kg}$ of vitamin $\mathrm{E}, 1,200 \mathrm{mg} / \mathrm{kg}$ of copper, $12 \mathrm{mg} / \mathrm{kg}$ of selenium, 200 $\mathrm{g} / \mathrm{kg}$ of calcium, $20 \mathrm{~g} / \mathrm{kg}$ of phosphorus, $320 \mathrm{~g} / \mathrm{kg}$ of salt, and $32 \mathrm{~g} / \mathrm{kg}$ of magnesium. The concentrates used consisted of $(\mathrm{g} / \mathrm{kg})$ rolled barley $(400)$, maize $(230)$, sugar beet pulp (170), soybean meal (160), molasses (30), and minerals (10) and were offered on top of the grass silage. The fatty acid profiles of the grass silage and concentrates are shown in Table 1.

A linseed supplement (TradiLin Valomega 160 BCC, Premium Crops Ltd., Hampshire, UK) composed of $0.70 \mathrm{~g}$ of linseed $/ \mathrm{kg}$ and $0.30 \mathrm{~g}$ of wheat $\mathrm{bran} / \mathrm{kg}$ (asfed) with a stated content of $155 \mathrm{~g}$ of C18:3n-3/kg (asfed) was also offered once daily on top of the silage/ concentrate diet at 4 amounts: $0,400,800$, or $1,200 \mathrm{~g}$ of supplement/animal per day. These 4 amounts were designed to supply each animal $0,112,224$, or $336 \mathrm{~g}$ of
Table 1. Fatty acid profile ( $\mathrm{g} / 100 \mathrm{~g}$ of fatty acids) in the basal diet

\begin{tabular}{lcc}
\hline \hline Falty acid & $\begin{array}{c}\text { Grass } \\
\text { silage }\end{array}$ & Concentrate \\
\hline C14:0 & 0.93 & 0.79 \\
C14:1 & 0.03 & 0.09 \\
C16:0 & 12.32 & 20.03 \\
C16:1n-7 & 0.38 & 0.50 \\
C17:0 & 0.14 & 0.17 \\
C18:0 & 2.09 & 4.58 \\
C18:1n-7 & 0.35 & 0.99 \\
C18:1n-9 & 2.00 & 16.26 \\
C18:2n-6 & 10.25 & 36.73 \\
C18:2 cis, trans & 0.03 & 0.07 \\
C18:2 trans, cis & ND & ND \\
C18:2 trans, trans & 0.02 & 0.07 \\
C18:3n-3 & 68.90 & 17.63 \\
C18:3n-6 & 0.32 & 0.04 \\
C18:4n-3 & ND & ND \\
C20:0 & 0.01 & 0.09 \\
C20:3n-6 & 0.01 & 0.02 \\
C20:4 & 0.16 & 0.02 \\
C20:4n-6 & $N D$ & ND \\
C20:5 & 0.10 & 0.09 \\
C20:5n-3 & ND & ND \\
C22:0 & 0.83 & 0.14 \\
C22:4n-6 & 0.81 & 0.29 \\
C22:5n-3 & 0.02 & 0.05 \\
C22:6n-3 & 0.02 & 0.02 \\
CLA & 0.30 & 1.34 \\
\hline & &
\end{tabular}

${ }^{1} \mathrm{ND}=$ not detected.

oil/d. The fatty acid composition of the supplement is shown in Table 2.

For each of the dietary treatments, concentrate intake was adjusted to ensure that total estimated ME intake from the supplement component of the diet (concentrate plus linseed) was constant across all treatments (Table 3). The dietary treatments were imposed for an average of $140 \pm 27 \mathrm{~d}$ during the finishing period.

\section{Animals and Management}

Dairy bulls $(\mathrm{n}=47 ; 19$ Holstein-Friesian, 10 Holstein $\times$ Norwegian, 8 Jersey $\times$ Holstein-Friesian, 6 Norwe-

Table 2. Fatty acid composition of the linseed supplement $^{1}$

\begin{tabular}{lc}
\hline \hline Fatty acid & Amount, g/100 g of fatty acids \\
\hline C16:0 & 5.50 \\
C16:1 & 0.10 \\
C17:0 & 0.10 \\
C18:0 & 3.50 \\
C18:1 $18: 2$ & 18.00 \\
C18:3n-3 & 17.30 \\
C20:0 & 55.00 \\
C20:1 & 0.20 \\
C20:3n-3 & 0.10 \\
C22:0 & 0.10 \\
C24:0 & 0.10 \\
\hline
\end{tabular}

${ }^{1}$ Valomega 160 BCC (Premium Crops Ltd., Hampshire, UK). 
Table 3. Description of the 4 dietary treatments (as-fed basis), showing the quantity of linseed supplementation and adjusted concentrate allowance to balance $\mathrm{ME}$ and $\mathrm{CP}$

\begin{tabular}{|c|c|c|c|c|c|c|}
\hline Treatment & $\begin{array}{c}\text { No. of } \\
\text { replications }\end{array}$ & $\begin{array}{l}\text { Valonega, } \\
\text { kg/animal } \\
\text { per day }\end{array}$ & $\begin{array}{c}\text { Basal concentrate, } \\
\mathrm{kg} / \text { animal } \\
\text { per day }\end{array}$ & $\begin{array}{c}\text { Total } \\
\text { concentrate } \\
\text { intake, } \mathrm{kg} / \text { animal } \\
\text { per day }\end{array}$ & $\begin{array}{c}\text { Concentrate } \mathrm{ME}^{3} \\
\text { intake, MJ/animal } \\
\text { per day }\end{array}$ & $\begin{array}{c}\mathrm{CP}^{3} \text { intake, } \\
\mathrm{g} / \text { animal } \\
\text { per day }\end{array}$ \\
\hline 1 & 3 & 0.0 & 6.0 & 6.0 & 68.4 & 876 \\
\hline 2 & 3 & 0.4 & 5.4 & 5.8 & 68.0 & 864 \\
\hline 3 & 3 & 0.8 & 4.8 & 5.6 & 68.7 & 867 \\
\hline 4 & 3 & 1.2 & 4.2 & 5.4 & 68.2 & 856 \\
\hline
\end{tabular}

${ }^{1}$ Number of pens of 4 animals fed each diet.

${ }^{2}$ Linseed supplement (TradiLin Valomega $160 \mathrm{BCC}$, Premium Crops Ltd., Hampshire, UK) composed of $0.70 \mathrm{~g}$ of linseed and $0.30 \mathrm{~g}$ of wheat bran with a stated content of $155 \mathrm{~g}$ of $\mathrm{C} 18: 3 \mathrm{n}-3 / \mathrm{kg}$.

${ }^{3} \mathrm{ME}$ and CP concentration of ingredients based on Agriculture, Food and Research Council (1993) recommendations.

gian, and 4 Norwegian $\times$ Holstein-Friesian) from the clairy herd at the Agri-Food and Biosciences Institute (Hillsborough, Co. Down, Northern Ireland) were used in the trial. The birth period was from January 15 to March 28, 2005. At the beginning of the study, cattle were $373 \pm 29.0 \mathrm{~kg}$ of BW and were on average $355 \pm$ $21.5 \mathrm{~d}$ of age. Initially, 48 animals were allocated to this study. At the onset of the finishing period, however, I animal had to be removed from the study to have individual treatment for a claw injury. The remaining animals entered the finishing period and were divided into 12 approximately uniform groups of 4 according to genotype, BW, conformation score, and age, and 1 animal in each group was allocated at random to each of the 4 dietary treatments based on linseed supplement amount $(\mathrm{g} / \mathrm{d}): 0(\mathrm{n}=12), 400(\mathrm{n}=12), 800$ $(n=11)$, and $1,200(n=12)$. Animals were housed in groups of 4 corresponding to a dietary treatment, so there were 3 pens of 4 animals for each treatment. Target BW at slaughter was $540 \mathrm{~kg}$ and the animals were slaughtered in 3 batches after 120,147, and 185 $\mathrm{d}$ on the experiment. The digital cushion samples from 1 Holstein $\times$ Norwegian on the 800-g treatment were not properly vacuum sealed before storage and therefore were not analyzed, so this treatment was reduced to $\mathrm{n}=10$.

\section{Fat Content and Fatty Acid Analysis}

At slaughter, right hind legs were cut below the tarsal joint and collected for sampling. If sampling occurred within $2 \mathrm{~d}$ of slaughter, legs were stored at $4^{\circ} \mathrm{C}$; otherwise, they were stored at $-20^{\circ} \mathrm{C}$ and then thawed overnight at room temperature before dissection.

After removal of the horn capsules (Ossent and Lischer, 1997), the cushions of the right lateral hind hooves were dissected and samples were collected from 6 different locations ( $A$ to F; Figure 1), using the methodology described by Räber et al. (2006). Individual digital cushion samples (A to F; Figure 1) were finely chopped and a $0.5-\mathrm{g}$ subsample was removed for lipid extraction. Lipids were extracted by accelerated solvent extraction (ASE, Dionex AG, Olten, Switzerland) with chloroform:methanol [2:1 (vol/vol)] according to the method of Folch et al. (1957). The extracted lipids were weighed and expressed as a proportion (\%) of the fresh tissue (grams of lipid/100 g of tissue). An aliquot of the extracted lipids was transformed to methyl esters using methanolic sodium hydroxide and boron trifluoride according to the method of Morrison and Smith (1964). The fatty acid composition was then determined by gas chromatography (Scientific Glass Engineering, Milton Keynes, UK) using a BP 20 fused-silica capillary column $(25 \mathrm{~m} \times 22 \mu \mathrm{m})$ with helium as the carrier gas. Fatty acids were expressed as percentage of fatty acids present.

\section{Statistical Analysis}

Data were evaluated using Genstat (Lawes Agricultural Trust, Rothamsted Experimental Rèsearch Station, Harpenden, Hertfordshire, UK). Covariates were tested for model inclusion by ANOVA in a split-plot analysis with 12 main plots constituting the 3 pens per dietary treatment and with the fat pads of the 4 animals within the pen as the subplots. Thus, there were 4 replicate subplots per fat pad within each main plot. Initially, all covariates were included (initial age, age at slaughter, initial BW, days on experiment, and lipid content). There were differences in the lipid content at different locations within the digital cushion. For this reason, lipid content was the only covariate retained in the present analysis. The effect of genotype was tested by adding it to the fixed model as a fàctor. Because this caused the design to become unbalanced, this was performed using REML analysis. The effect of genotype did not contribute to the variation between treatments and therefore was not included in the final model. Data were ultimately analyzed by ANOVA. For fatty acid analyses, diet, location (A to F), and their interactions were included in the analysis as fixed effects, with lipid content (g/100 g of tissue) as a covariate. Effects of linseed supplementation were tested for linear and quadratic contrasts using $P \leq 0.05$ as the cutoff for significant differences and $P<0.1$ for trends. Lipid content of the individual digital cushion locations was also tested by ANOVA, with cliet, location ( $\mathrm{A}$ to $\mathrm{F}$ ), and their interactions as fixed effects. 


\section{RESULTS}

Silage DMI, total DMI, and BW gain from the beginning of the trial until slaughter were not significantly affected by dietary treatment (Dawson et al., 2007). The average slaughter weight was $549 \mathrm{~kg}$ and $\mathrm{BW}$ gain throughout the experimental period averaged $1.3 \mathrm{~kg} / \mathrm{d}$. No animals showed evidence of sole lesions on the plantar surface of hooves dissected for this study.

\section{Lipid Content and Fatty Acid Composition of the Digital Cushion}

Total lipid content (grams of fatty acid/100 $\mathrm{g}$ of tissue) varied by sample location $(A=30.01, B=13.26$, $\mathrm{C}=20.31, \mathrm{D}=24.78, \mathrm{E}=5.54$, and $\mathrm{F}=3.08$; average SEM 1.23; $P<0.001$ ) but did not vary with diet. The effect of dietary treatment on the concentration of fatty acids in the digital cushion is shown in Table 4. Although the proportion of $\mathrm{C} 18: 3 \mathrm{n}-3$ was not different across treatments, a linear relationship was observed between increasing linseed supplementation and the concentration of C18:311-3:total PUFA (positive relationship; $P=0.05$ ). A trend toward a positive linear relationship was shown between linseed in the diet and C20:4n-6 $(P=0.09)$.

There was a quadratic effect of linseed supplementation on the concentration of several fatty acids in the digital cushion. Linseed supplementation resulted in a quadratic increase in $\mathrm{C} 18: 0(P=0.001), \mathrm{C} 18: 2 \mathrm{n}-6(P$ $=0.008), \mathrm{C} 18: 3 \mathrm{n}-6(P=0.02), \mathrm{C} 18: 4 \mathrm{n}-3(P=0.005)$, total PUFA $(P=0.003)$, total n-6 PUFA $(P=0.006)$, and the PUFA:SFA ratio $(P=0.006)$, with overall C18 showing a similar trend $(P=0.06)$. The concentration of C14:1 $(P=0.03)$, total MUFA $(P=0.002)$, and overall C16 $(P=0.02)$ decreased quadratically as the amount of linseed increased, with bulls offered 400 or $800 \mathrm{~g}$ of linseed supplement/d having decreased concentrations compared with bulls offered $1,200 \mathrm{~g} / \mathrm{d}$. The content of C16:1n-7 $(P=0.06)$ showed a similar trend.

Eicosapentaenoic acid (C20:5n-3, EPA) was detected in only 4 samples in total [proportion of the total fatty acids present: 0.2 in section $F(n=1)$ and 0.3 in section $E(n=3)$ from animals on various linseed treatments] and was therefore not tested statistically. Docosapentaenoic acid (C22:5n-3) was detected in 19 samples (out of 276). Docosapentaenoic acid was mainly found in location $\mathrm{F}$ (15 out of the 19 samples), with the remainder found in $B(n=1)$ or $E(n=3)$. As a percentage of the total fatty acid methyl esters in these 19 samples, docosapentaenoic acid ranged from 0.1 to 0.7 (mean = $0.4 ; \mathrm{SD}=0.19$ ).

\section{Fatty Acid Composition by Location}

In certain cases, the fatty acid composition varied by sample location. Table 5 shows the proportion of various fatty acids by location ( $A$ to $F$ ) in the digital cushion of animals on the 1,200-g linseed supplement/d treatment.

\section{DISCUSSION}

The animals in the current study were slaughtered at approximately 18 mo of age, when a large proportion of whitish, less fatty digital cushions would be expected (Räber et al., 2004). Although not included in the observation protocol for this study, some informal

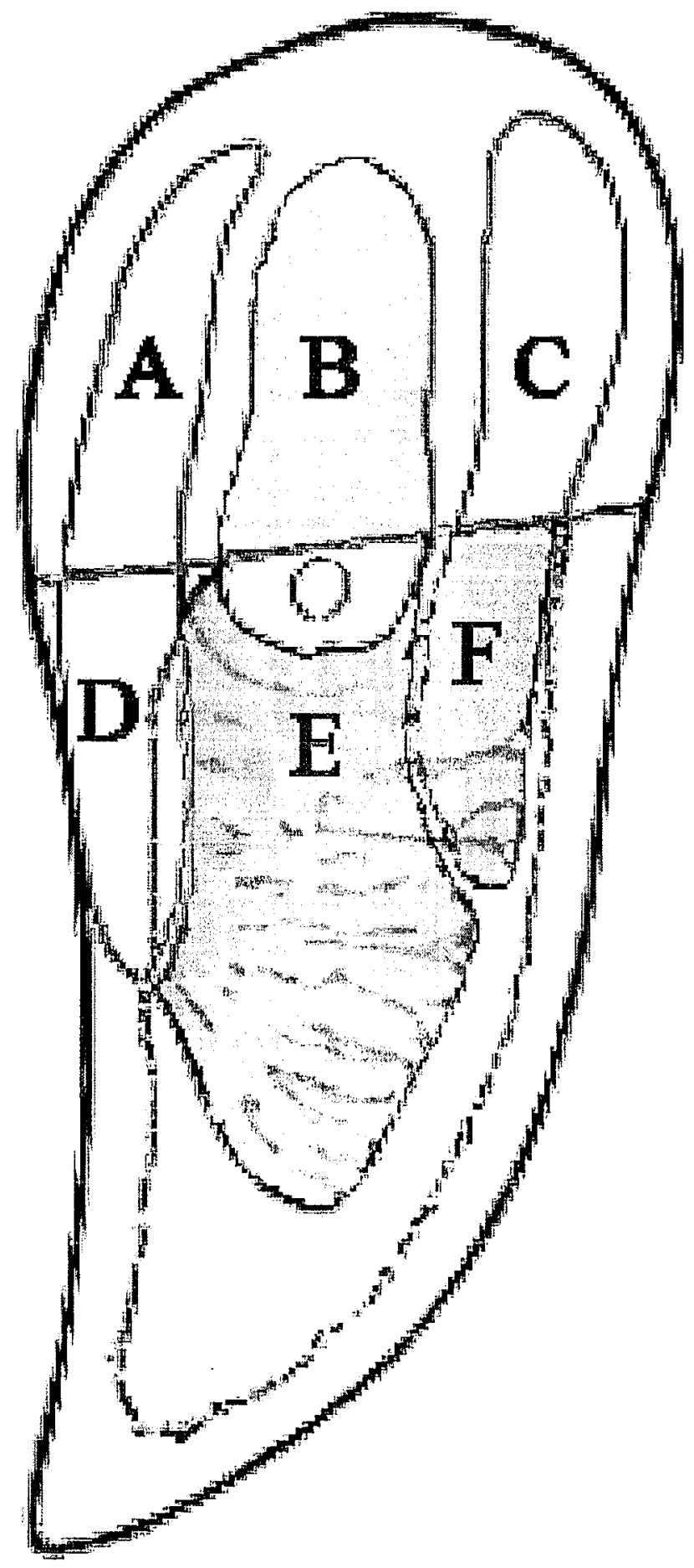

Figure 1. Schematic drawing of the digital cushion of the bovine claw showing the different sample locations (A to F; Räber et al., 2006). 
Table 4. Effect of substituting a proportion of the concentrate in grass silage/concentrate-based diets with extruded linseed on concentration of individual fatty acids ( $\mathrm{g} / 100 \mathrm{~g}$ of fatty acids) in the digital cushion

\begin{tabular}{|c|c|c|c|c|c|c|c|c|c|}
\hline \multirow[b]{2}{*}{$\begin{array}{l}\text { Fatty acid, } \mathrm{g} / 100 \mathrm{~g} \\
\text { of fatty acids }\end{array}$} & \multicolumn{4}{|c|}{$\begin{array}{l}\text { Linseed supplement, } \\
\text { g/animal per day }\end{array}$} & \multirow[b]{2}{*}{$\begin{array}{l}\text { Maximum } \\
\mathrm{SEM}^{2}\end{array}$} & \multirow[b]{2}{*}{$\begin{array}{l}\text { Estimated } \mathrm{SE} \text {, } \\
\text { minimum- } \\
\text { maximum }{ }^{3}\end{array}$} & \multicolumn{3}{|c|}{$P$-value ${ }^{4}$} \\
\hline & $\begin{array}{c}0 \\
\mathrm{n}=3 \\
(12)\end{array}$ & $\begin{array}{c}400 \\
\mathrm{n}=3 \\
(12)\end{array}$ & $\begin{array}{c}800 \\
\mathrm{n}=3 \\
(10)\end{array}$ & $\begin{array}{c}1,200 \\
\mathrm{n}=3 \\
(12)\end{array}$ & & & Treatment & Linear & Quadratic \\
\hline $\mathrm{C} 14: 0$ & 1.30 & 1.22 & 1.27 & 1.29 & 0.07 & 0.05 & 0.69 & 0.98 & 0.35 \\
\hline $\mathrm{C} 14: 1$ & 1.63 & 1.35 & 1.35 & 1.69 & 0.15 & 0.11 & 0.12 & 0.75 & 0.03 \\
\hline C15:0 & 0.16 & 0.18 & 0.14 & 0.11 & 0.06 & 0.05 & 0.78 & 0.41 & 0.63 \\
\hline $\mathrm{C} 16: 0$ & 14.98 & 13.81 & 14.49 & 14.58 & 0.37 & 0.27 & 0.08 & 0.60 & 0.04 \\
\hline C16:1n-7 & 11.93 & 10.99 & 10.54 & 12.00 & 0.72 & 0.54 & 0.23 & 0.94 & 0.06 \\
\hline C17:0 & 0.69 & 0.67 & 0.67 & 0.66 & 0.03 & 0.02 & 0.81 & 0.34 & 0.95 \\
\hline C18:0 & 2.41 & 3.38 & 3.48 & 2.20 & 0.30 & 0.22 & 0.01 & 0.60 & 0.001 \\
\hline C18:1n-7 + C18:1n-9 & 63.79 & 63.49 & 63.89 & 63.96 & 1.01 & 0.75 & 0.97 & 0.80 & 0.79 \\
\hline C18:2n-6 & 2.03 & 2.86 & 2.36 & 2.07 & 0.22 & 0.16 & 0.02 & 0.70 & 0.01 \\
\hline C18:3n-6 & 0.30 & 0.48 & 0.40 & 0.41 & 0.05 & 0.04 & 0.04 & 0.10 & 0.02 \\
\hline C18:3n-3 & 0.24 & 0.32 & 0.29 & 0.33 & 0.04 & 0.03 & 0.27 & 0.13 & 0.48 \\
\hline C18:4n-3 & 0.22 & 0.39 & 0.38 & 0.27 & 0.05 & 0.04 & 0.03 & 0.46 & 0.01 \\
\hline C20:4n-6 & 0.31 & 0.21 & 0.46 & 0.77 & 0.27 & 0.20 & 0.29 & 0.09 & 0.46 \\
\hline $\mathrm{C} 22: 6 \mathrm{n}-3$ & 0.30 & 0.22 & 0.15 & 0.58 & 0.19 & 0.14 & 0.20 & 0.26 & 0.13 \\
\hline SFA & 19.54 & 19.24 & 20.05 & 18.84 & 0.40 & 0.30 & 0.11 & 0.30 & 0.19 \\
\hline MUFA & 77.35 & 75.82 & 75.79 & 77.65 & 0.49 & 0.36 & 0.01 & 0.60 & 0.002 \\
\hline PUFA & 3.09 & 4.93 & 4.17 & 3.52 & 0.40 & 0.30 & 0.01 & 0.62 & 0.003 \\
\hline PUFA n-6 & 2.58 & 3.96 & 3.28 & 2.79 & 0.34 & 0.25 & 0.02 & 0.94 & 0.01 \\
\hline PUFA n-3 & 0.51 & 0.98 & 0.89 & 0.73 & 0.09 & 0.07 & 0.01 & $0.09 \mathrm{~m}$ & 0.002 \\
\hline C16 & 26.91 & 24.79 & 25.03 & 26.58 & 0.84 & 0.62 & 0.10 & 0.77 & 0.02 \\
\hline $\mathrm{C} 18$ & 69.00 & 70.92 & 70.86 & 69.24 & 1.11 & 0.82 & 0.26 & 0.84 & 0.06 \\
\hline n-3:total PUFA & 0.17 & 0.23 & 0.24 & 0.23 & 0.03 & $0.02^{\circ}$ & 0.14 & 0.07 & 0.13 \\
\hline C18:3n-3:total PUFA & 0.08 & 0.10 & 0.09 & 0.13 & 0.01 & 0.01 & 0.05 & 0.01 & 0.26 \\
\hline PUFA:SFA & 0.16 & 0.26 & 0.21 & 0.19 & 0.02 & 0.02 & 0.02 & 0.53 & 0.01 \\
\hline$n-6: n-3$ & 0.23 & 0.31 & 0.32 & 0.37 & 0.07 & 0.06 & 0.37 & $0.11 \ldots$ & 0.71 \\
\hline
\end{tabular}

'The number of animals fed each treatment is shown in parentheses. (Note the 800-g diet had only 10 animals in the analysis because 2 groups in this treatment were reduced to 3 , whereas the others had 4 animals per group.)

${ }^{2}$ Maximum replicate SEM used for comparing among the treatments with 12 animals.

${ }^{3}$ For comparing the $800-\mathrm{g}$ treatment with any of the other treatments.

"Treatment, linear, and quadratic refer, respectively, to an overall test of the significance of the differences between all 4 treatinent means (on $3 \mathrm{df}$ ) and the significance of tests of linear and quadratic contrasts of the means (each on $1 \mathrm{df}$ ).

observations were made regarding the appearance of the digital cushions. In many cases, the digital cushions from animals on this study were composed of smooth yellow adipose tissue. In particular, sections $A, B, C$, and sometimes $\mathrm{D}$ appeared yellow and fatty in several hooves, whereas the sections under the pedal bone ( $D$ to F) were more often whitish pink and appeared less fatty. This roughly corresponds to the lipid content measured in these sections.

\section{Fatty Acid Composition}

The assay used in the current study did not measure CLA. However, animals in this study were also involved in a performance and meat quality study in which differences in CLA were reported in tissues used for human consumption (Dawson et al., 2010).

The content of the various fatty acids in the digital cushion were quite different from those of other adipose depots. For instance, in studies investigating the effects of feeding linseed on beef performance and carcass characteristics, Maddock et al. (2006) and Noci et al. (2007) reported quantities of C18:0 that were at least 1.5 times greater and quantities of $\mathrm{C} 18: 1$ and total MUFA that were approximately 1.5 times less than those reported here for the digital cushion. Räber et al. (2006) suggested that the functional differences between the tissues tested contribute to this discrepancy. It is believed that the digital cushion acts as a shock absorber in cattle hooves and that this function results in compositional differences compared with adipose tissue used for energy storage.

MUFA. Räber et al. (2006) reported concentrations of total MUFA, and specifically oleic acid, (C18:1) in the digital cushions of Brown Swiss cows and heifers that were similar to those described in the current study. Total MUFA concentration in the digital cushions of animals in this study showed a quadratic decrease with increasing amounts of linseed in the diet.

$P U F A$. There were quadratic responses to increasing linseed supplementation amount for several longer chain fatty acids, both SFA and PUFA (C18:0, C18:2n-6, C18:3n-6, C18:4n-3, C20:4n-6, overall C18, total n-3 PUFA, total n-6 PUFA, and the PUFA:SFA 
Table 5. Proportion of various fatty acids by location (A to F) ${ }^{1}$ in the digital cushion of animals on the 1,200-g linseed supplement/d treatment $(\mathrm{n}=3)$

\begin{tabular}{|c|c|c|c|c|c|c|c|c|}
\hline \multirow{2}{*}{$\begin{array}{l}\text { Fatty acid, } \\
\mathrm{g} / 100 \mathrm{~g} \text { of } \\
\text { fatty acids }\end{array}$} & \multicolumn{6}{|c|}{ Digital cushion location } & \multirow[b]{2}{*}{ SEM } & \multirow[b]{2}{*}{$P$-value } \\
\hline & $\mathrm{A}$ & $\mathrm{B}$ & C & $\mathrm{D}$ & $\mathrm{E}$ & $\mathrm{F}$ & & \\
\hline C14:0 & 1.3 & 1.32 & 1.27 & 1.3 & 1.27 & 1.25 & 0.06 & 0.93 \\
\hline $\mathrm{C} 14: 1$ & $1.69^{\mathrm{abse}}$ & $1.51^{\mathrm{ab}}$ & $1.69^{\mathrm{nbc}}$ & $1.95^{\mathrm{d}}$ & $1.83^{\mathrm{cd}}$ & $1.44^{\mathrm{a}}$ & 0.13 & $<0.001$ \\
\hline $\mathrm{C} 15: 0$ & $0.09^{\mathrm{a}}$ & $0.04^{\mathrm{a}}$ & $0.06^{\mathrm{a}}$ & $0.07^{\mathrm{a}}$ & $0.17^{\mathrm{ab}}$ & $0.25^{\mathrm{b}}$ & 0.07 & 0.06 \\
\hline $\mathrm{C} 16: 0$ & $15.89^{d}$ & $15.23^{\mathrm{cd}}$ & $14.37^{\mathrm{bc}}$ & $14.88^{\mathrm{c}}$ & $13.83^{\text {ab }}$ & $13.28^{\mathrm{a}}$ & 0.48 & $<0.001$ \\
\hline C16:1n-7 & $11.70^{\text {ab }}$ & $11.23^{\mathrm{a}}$ & $12.15^{\mathrm{abcd}}$ & $13.03^{\mathrm{d}}$ & $12.85^{\mathrm{bed}}$ & $11.03^{\mathrm{a}}$ & 0.59 & $<0.001$ \\
\hline $\mathrm{C} 17: 0$ & $0.65^{\mathrm{b}}$ & $0.62^{\mathrm{ab}}$ & $0.54^{\mathrm{n}}$ & $0.62^{\mathrm{nb}}$ & $0.67^{\mathrm{b}}$ & $0.84^{\circ}$ & 0.05 & $<0.001$ \\
\hline $\mathrm{C} 18: 0$ & $1.56^{\text {tb }}$ & $2.39^{\mathrm{ab}}$ & $1.69^{\mathrm{ab}}$ & $1.26^{\mathrm{n}}$ & $2.56^{\mathrm{b}}$ & $3.76^{\circ}$ & 0.59 & 0.007 \\
\hline C18:1n-7 + C18:1n-9 & $65.40^{\mathrm{b}}$ & $65.45^{\mathrm{b}}$ & $66.34^{b}$ & $64.88^{\mathrm{b}}$ & $61.72^{\mathrm{n}}$ & $59.98^{n}$ & 1.42 & $<0.001$ \\
\hline $\mathrm{C} 18: 2 n-6$ & $0.94^{\mathrm{B}}$ & $1.25^{\mathrm{a}}$ & $1.04^{\mathrm{a}}$ & $1.08^{a}$ & $2.98^{\mathrm{b}}$ & $5.16^{\mathrm{c}}$ & 0.62 & $<0.001$ \\
\hline$C 18: 3 n-6$ & 0.45 & 0.36 & 0.37 & 0.44 & 0.39 & 0.44 & 0.05 & 0.27 \\
\hline C18:3n-3 & 0.26 & 0.28 & 0.35 & 0.29 & 0.39 & 0.38 & 0.06 & 0.18 \\
\hline$C 18: 4 n-3$ & $0.33^{\mathrm{b}}$ & $0.28^{\mathrm{ab}}$ & $0.21^{\mathrm{a}}$ & $0.26^{\mathrm{ab}}$ & $0.22^{\mathrm{a}}$ & $0.30^{\mathrm{b}}$ & 0.04 & 0.005 \\
\hline $\mathrm{C} 20: 4 \mathrm{Il}-6$ & 0.84 & 0.34 & 0.50 & 0.71 & 0.97 & 1.27 & 0.56 & 0.30 \\
\hline $\mathrm{C} 22: 6 \mathrm{n}-3$ & $0.54^{\mathrm{ab}}$ & $0.43^{\mathrm{a}}$ & $0.48^{\mathrm{n}}$ & $0.54^{\mathrm{ab}}$ & $0.54^{\mathrm{ab}}$ & $0.95^{\mathrm{b}}$ & 0.23 & 0.04 \\
\hline SFA & 19.5 & 19.59 & 17.93 & 18.13 & 18.49 & 19.38 & 0.93 & 0.23 \\
\hline MUFA & $78.78^{b c}$ & $78.20^{\text {be }}$ & $80.18^{\mathrm{e}}$ & $79.85^{\mathrm{bc}}$ & $76.41^{\mathrm{b}}$ & $72.46^{\mathrm{a}}$ & 1.80 & 0.002 \\
\hline PUFA & $1.77^{n}$ & $2.24^{\mathrm{a}}$ & $1.83^{\mathrm{n}}$ & $1.98^{\mathrm{n}}$ & $5.04^{b}$ & $8.26^{\mathrm{c}}$ & 1.04 & $<0.001$ \\
\hline PUFA n-6 & $1.24^{\mathrm{a}}$ & $1.64^{\mathrm{a}}$ & $1.32^{\mathrm{u}}$ & $1.46^{\mathrm{a}}$ & $4.18^{\mathrm{b}}$ & $6.93^{\mathrm{c}}$ & 9.80 & $<0.001$ \\
\hline PUFA n-3 & $0.53^{n}$ & $0.61^{\mathrm{ab}}$ & $0.51^{\mathrm{a}}$ & $0.52^{\mathrm{n}}$ & $0.85^{\mathrm{b}}$ & $1.34^{c}$ & 0.14 & $<0.001$ \\
\hline $\mathrm{C} 16$ & $27.59^{\mathrm{lxc}}$ & $26.46^{\mathrm{b}}$ & $26.52^{\mathrm{b}}$ & $27.91^{\circ}$ & $26.69^{\mathrm{bc}}$ & $24.31^{\mathrm{a}}$ & 0.66 & $<0.001$ \\
\hline $\mathrm{C} 18$ & $68.95^{\mathrm{nh}}$ & $70.01^{b}$ & $70.01^{\mathrm{b}}$ & $68.21^{A}$ & $68.26^{\mathrm{n}}$ & $69.99^{\mathrm{b}}$ & 0.72 & 0.007 \\
\hline
\end{tabular}

${ }^{n-d}$ Within a row, means without a common superscript differ significantly in a 2-sided $t$-test $(P<0.05)$.

${ }^{1}$ See Figure 1.

ratio) in the digital cushion. Bulls offered 400 or 800 $\mathrm{g}$ of linseed supplement/d had greater concentrations of these fatty acids compared with those offered the control diet. This was coupled with a concomitant quadratic decrease in shorter chain fatty acids (C14:1, C16:1n-7, total MUFA, and overall C16). This suggests that a threshold limit of PUFA for incorporation in the digital cushion had been met in the $1,200 \mathrm{~g} / \mathrm{d}$ treatment and that these shorter chain, more SFA were preferentially incorporated.

Although there was no difference in the total C18:3n-3 across treatments, as linseed supplementation increased, there was a linear increase in C18:3n-3 as a proportion of total PUFA. Dawson et al. (2007) found similar relationships in the muscle (LM) of these animals. Eicosanoids, 20-carbon hormones made from n-3 and n-6 fatty acids, often have opposing roles (i.e., anti-inflammatory and inflammatory functions; Kelley, 2001). If both types of fatty acids are present, they will compete to be transformed into eicosanoids, so the ratio of $n-6$ and $n-3$ fatty acids directly influences the type of eicosanoids produced (Kelley, 2001). As such, the amount and type of dietary fatty acids could potentially alter immune and inflammatory responses. In particular, n-3 fatty acids have been suggested as potential therapeutic agents for inflammatory diseases (Simopoulos, 1991). Many lesions in cattle hooves are a consequence of inflammation within the claw capsule; therefore, increasing dietary intake of n-3 fatty acids could help moderate the inflammatory reaction, which may be beneficial in hooves with edema.
Arachidonic acid (C20:4n-6) showed a trend toward a linear increase with increased linseed supplementation. Räber et al. (2006) proposed that C20:4n-6, an $\mathrm{n}-6$ PUFA used for the production of eicosanoids with inflammatory activity, was stored in the digital cushion to be used in the production of inflammatory mediators. According to Räber et al. (2006), who reported significant differences in the concentration of C20:4n-6 in the digital cushions of cows and heifers, C20:4n-6 was potentially used up in the production of inflammatory mediators in the cushions of older cows. Very few hooves of animals on the current study showed any signs of sole lesions and none had ulcers, which could partially explain the greater $\mathrm{C} 20: 4 \mathrm{n}-6$ values reported here. Räber et al. (2006) theorized that increasing the amount of dietary C18:3n-3 would clecrease the production of C20:4n-6 and increase the availability of eicosanoids with anti-inflammatory and immunosuppressive activities, and would therefore be beneficial for claw health. Our results, however, show conflicting evidence because both the concentration of C20:4n-6 (an $\mathrm{n}-6$ PUFA) and the C18:3n-3 as a proportion of total PUFA increased linearly.

Linolenic acid (C18:3n-3) can be used to synthesize the n-3 PUFA EPA and docosahexaenoic acid (DHA). Contrary to previous research on muscle tissue (Scollan et al., 2001), extruded linseed had no significant effect on EPA (C20:5n-3) concentrations in the digital cushion. Eicosapentaenoic acid was undetected in most digital cushion samples. This is of interest because eicosanoids derived from EPA have been shown to be 
beneficial in treating inflammatory disorders in humans (Simopoulos, 1999) and thus could potentially help mediate chronic inflammation problems in cattle hooves. Interestingly, although EPA was not detected, DHA was present in the digital cushion. The treatments, however, had no influence on the amount of DHA in the cushion. The lack of a dietary effect on some of the long-chain fatty acids suggests that the extrusion treatment of the linseed was not sufficient to increase the availability of C18:3n-3 to such an extent as to allow enhanced synthesis of eicosanoids with anti-inflammatory activity.

\section{Location Differences in Fatty Acid Composition of the Digital Cushion}

Locations $\mathrm{E}$ and $\mathrm{F}$ had the least lipid content in our study and in earlier studies; thus, as reported previously by other researchers (Räber et al., 2006), we would expect these locations to have more MUFA. In contrast, however, these locations with the least lipid content simultaneously showed the smallest proportion of MUFA. Räber et al. (2006) reported their result based on combined data from 6 cows and 6 heifers. Perhaps there is an age effect that we did not observe in the current study because the animals in the current study were slaughtered at approximately $18 \mathrm{mo}$ of age, without the stresses of calving and of housing and management changes, which have been linked with increased lameness in dairy cows and heifers. Thus, the hypothesis suggested by Räber et al. (2006), that the cow compensates for the decreased lipid content in these locations by having softer fat (with more MUFA), was not tested in the present study.

This work demonstrates the influence of dietary fatty acid composition on the proportion of various fatty acids deposited in the digital cushion. It is possible to inanipulate the type of fat deposited in cattle digital cushion tissues by feeding PUFA-rich supplements. There appears to be an optimal quantity of supplementation of linseed, after which the deposition of PUFA in the digital cushion decreases, as observed in the current study in the $1,200 \mathrm{~g} / \mathrm{d}$ treatment.

New research must further elucidate the role of the digital cushion in cattle lameness and the occurrence of sole lesions. If a digital cushion of a certain composition is found to be more supportive or protective in cattle hooves, the relationships between diet and fatty acids shown here must be considered when altering diets to change the fatty acid composition of the digital cushion.

\section{LITERATURE CITED}

Agriculture, Food and Research Council. 1993. Energy and Protein Requirements of Ruminants: An Advisory Manual Prepared by the AFRC Technical Committee on Responses to Nutrients. CAB Int., Wallingford, UK.

Dawson, L. E. R., A. M. Fenron, B. W. Moss, and V. B. Woods. 2007. Effect of substitution of a proportion of the concentrate in grass silage/concentrate-based diets with extruded linseed on performance and meat quality of dairy bulls. Page 10 in Proc. Brit. Soc. Anim. Sci., Southport, UK.

Dawson, L. E. R., A. M. Fearon, B. W. Moss, and V. B. Woods. 2010. Effects of substitution of a proportion of the concentrate in grass silage/concentrate-based diets with extruded linseed on performance and meat quality of dairy bulls. Anim. Feed Sci. Technol. 156:10-18.

Folch, J., M. Lees, and G. H. Sloane-Stanley. 1957. A simple method for the isolation and purification of total lipids from animal tissues. J. Biol. Chen. 226:497-509.

Gläser, K. R., C. Wenk, and M. R. L. Scheeder. 2004. Evaluation of pork backfat firmness and leurd consistency using several different physicochemical methods. J. Sci. Food Agric. 84:853-862.

Kelley, D. S. 2001. Modulation of human immune and inflammatory responses by dietary fatty acids. Nutrition 17:669-673.

Lischer, C. J., U. Koller, H. Geyer, C. Mulling, J. Schulze, and P. Ossent. 2002. Effect of therapeutic dietary biotin on the healing of uncomplicated sole ulcers in dairy cattle-A double blinded controlled study. Vet. J. 163:51-60.

Maddock, T. D., M. L. Bauer, K. B. Koch, V. I. Anderson, R. J. Maddock, G. Barceló-Coblijn, E. J. Murphy, and G. P. Lardy. 2006. Effect of processing flax in beef feedlot diets on performance, carcass characteristics, and trained sensory panel ratings. J. Anim. Sci. 84:1544-1551.

Morrison, W. R., and L. M. Smith. 1964. Preparation of fatty acid methyl esters and dimethylacetals from lipids with boron trifluoride methanol. J. Lipid Res. 5:600-608.

Noci, F., P. French, F. J. Monahan, and A. P. Moloney. 2007. The fatty acid composition of muscle fat and subcutaneous adipose tissue of grazing heifers supplemented with plaint oil-enriched concentrates. J. Anim. Sci. 85:1062-1073.

Ossent, P., and C. Lischer. 1997. Post mortem examination of the hooves of cattle, horses, pigs and small ruminants under practice conditions. In Pract. 19:21-29.

Räber, M. 2000. Das Ballenpolster beim Rind-Ein Beitrag zur funktionellen Anatomie cler Klaue. $\mathrm{PhD}$ Diss. Universität Zürich, Switzerland.

Räber, M., C. J. Lischer, H. Geyer, and P. Ossent. 2004. The bovine digital cushion-A descriptive anatomical study. Vet. J. 167:258-264.

Räber, M., M. R. L. Scheeder, P. Ossent, C. J. Lischer, and H. Geyer. 2006. The content and composition of lipids in the digital cushion of the bovine claw with respect to age and location--A preliminary report. Vet. J. 172:173-177.

Scollan, N. D., N.-J. Choi, E. Kurt, A. V. Fisher, M. Enser, and J. D. Wood. 2001. Manipulating the fatty acid composition of muscle and adipose tissue in beef cattle. Br. J. Nutr. 85:115-124.

Simopoulos, A. P. 1991. Omega-3 fatty acids in health and disease and in growth and development. Am. J. Clin. Nutr. 54:438463.

Simopoulos, A. P. 1999. Essential fatty acids in health and chronic disease. Am. J. Clin. Nutr. 70:560S-569S. 
